Vol. 6, No. 2, 2019

https://doi.org/10.23939/eem2019.02.100

UDC 657.471

JEL Classification Code M41

V. Orlova,
Ivano-Frankivsk National Technical University of Oil and Gas, Ukraine, PhD, Professor
ORCID: 0000-0003-3882-9191

S. Kafka,

Ivano-Frankivsk National Technical University of Oil and Gas, Ukraine, Doctor, Associate

Professor

ORCID: 0000-0002-6031-383X

O. Riabkova,

Lviv Polytechnic National University, Ukraine, $\mathrm{PhD}$, Senior Lecturer

E-mail: ryabkova1130@gmail.com

\title{
DECOMMISSIONING OF FIXED ASSETS AND LAND RECOVERY: ACCOUNTING AND ASSESSMENT
}

\begin{abstract}
The existing provisions and regulations for the accounting of the written-off objects of the fixed assets and the working balances creation to cover the expenses of land restoration were investigated. Taking into consideration the peculiarities of the Ukrainian enterprises activity in the field of oil and gas industry, the problematic aspects within the accounting of the fixed assets and other non- circulating assets were investigated. The structure of the expected expenses for decommissioning of fixed assets and land restoration, that are the specific objects of the oil and gas industry enterprises, was determined. Based on the reasoning for structural expenses, the conceptual basis for the creation of accounting methodology with the emphasis on the contents of operations for funds creation for the provision of expenditure for the subsequent periods to finance economic operations for decommissioning of fixed assets and the restoration of land in the oil and gas industry. It has been proven in this article that creation of amounts of securities for such aims of the enterprise, should be identified in accordance with such criteria as the planned level of changes of the possible stock for oil and gas mining. It is argued that at each of the following stages of the mineral wealth exploitation, to recognize such liabilities in the accounting system are necessary, taking into account the risks, associated with the decommissioning
\end{abstract}

of such assets. For the objective results provision, the general scientific methods of scientific knowledge, the specific methods of accounting and risk management methods were used.

Key words: costs for decommissioning, provision, obligations, accounting, fixed assets, assessment.

\section{Formulation of the problem}

At the moment, there are a number of uncoordinated issues in accounting for the deduction of individual costs for the non-current tangible assets of the original value. In particular, this applies to provisions National Accounting Standard 7 "Fixed assets" [1] and IAS 16 "Property, Plant and Equipment" [2], according to which the initial value of fixed assets increases with the simultaneous creation of collateral at the amount of the obligation that arises at the dismantling, relocation of the facility and bringing the land on which it is located into a condition suitable for further use (in particular, for the land reclamation provided for by law), i.e. the possibility and conditions for capitalization of costs. 
Relevance of the chosen topic

In connection with the peculiarities of the enterprises of the oil and gas industry, in the part of non-negotiable tangible assets a significant share is occupied by those who require considerable expenses for decommissioning and carrying out works for the restoration of land due to significant technological influence and contamination of natural complexes during normal operation of structures and systems of oil and gas assets. This fact actualizes the issue of expense financing sources creation in thesystem of accounting, taking into account the scientifically-grounded methodology of estimating the value of these processes provision. The existing debating provisions of modern accounting standardization in the sphere of assets assessment, the alternative methods of accounting statement of the initial costs and decommissioning of its consumed part constitute the problems raised in the article, and, accordingly, its aims.

\section{Analysis of recent research and publications}

In modern economic conditions, the correctness of the reflection in accounting for operations with nonnegotiable tangible assets of the enterprise remains a difficult part of accounting. The main problematic issues arise in the formation of the initial value of nonnegotiable tangible assets, on which they will be registered, put into operation, the determination and assessment of future costs for them, the accumulation of depreciation, expansion of its function as its own source of financing of the enterprise.

Such scientists and economists as A. P. Grinko [3, p. 110], Z.-M. V. Zadorozhny [4, p. 163], I. K. Kizo, D. J. Weigant, T. D. Warfield [5, p. 395398], S. A. Kuznetsova [6], Y. D. Krupka [7, p. 544549], B. Nedels, H. Anderson, D. Caldwell [8] devoted considerable attention to the study of the problems of accounting for non-negotiable tangible assets in their works. The results obtained by them are a significant contribution to improving the management of non-negotiable tangible assets based on the organic interconnection of accounting functions with other management functions. However, there remain a number of unresolved and debatable issues regarding the assessment and features of capitalization of costs associated with the decommissioning of fixed assets in the oil and gas industry and the restoration of land after the completion of the processes of subsoil use, which updates this study.
This fact actualizes the contents of the theme researches taking into account the national conditions of oil and gas industry enterprises' operation, in other words, forming the adaptive type of accounting methodology for the Ukrainian practice.

\section{Purpose and tasks}

The purpose of the article is to study the peculiarities of the formation of the initial cost of fixed assets and its reflection in the accounts of oil and gas industry enterprises in the conditions of the necessity of restoration of land plots and other expenses for the decommissioning of such means..

Accordingly, the tasks set out in the study are: to identify how the characteristics of the enterprises of the oil and gas industry affect the accounting of fixed assets and other non-negotiable tangible assets; determine the composition of expenses necessary for the decommissioning of fixed assets and the restoration of land plots; to elaborate schemes of accounting of operations for forming the provision of expenses for the decommissioning of fixed assets and the restoration of land plots; determine how changing of expected value estimates will affect the accuracy of accounting information to manage them..

\section{Description of the main study material and the results}

The main features of the oil and gas companies that influence the methodology and organization of accounting for non-current assets include: dependence on natural factors, heterogeneous composition of well drilling works, development of minerals, real estate mining process, long-term extraction, technological process of simultaneously producing several types of products, lack of work in progress, consistent implementation, continuity of the main production processes, the presence of specific components of non-tangible assets and others.

In accordance with the requirements of the current legislation [9] the decommissioning of wells, oil extraction equipment and the primary preparation of oil for transportation, other fixed assets there is an obligation to restore land. Such works include isolation and liquidation, rehabilitation of land regeneration, preservation of the estuaries and trunks of liquidated wells, periodicity of their inspection and restoration of land areas where extraction was carried out. 


\section{Orlova, S. Kafka, O. Riabkova}

The obligation to liquidate the wells occurs at the time of commissioning of the well and is recognized as a security, since this obligation arose as a result of past events, namely the construction of a well. The term of the obligation to liquidate the well associated with the period of obtaining economic benefits from the use of wells, and comes after the decision to eliminate the well. At the initial recognition of the provision, the amount of current expenses for the elimination of wells for each individual well is calculated, which takes into account the costs of performing such works on the basis of the cost estimates for the elimination of the well and the restoration of the land plot prepared by the technical services of the enterprise, taking into account the long-term inflation rate and discount rate.

Such costs are accounted for and measured in accordance with IAS 37 "Provisions, Contingent Liabilities and Contingent Assets" [10] and National Accounting Standard 11 "Liabilities" [11] and are included in the historical cost of property, plant and equipment in accordance with IFRS 16 "Property, Plant and Equipment" [2] and National Accounting Standard 7 "Fixed assets" [1], that is, capitalization of such costs is assumed.

The amount of pre-estimated expenses for the liquidation of non-current tangible assets is a component of their initial value and is amortized over the useful life of the asset. At the same time, provisions are recognized as a liability with an indefinite term or an indefinite amount. As noted by T. I. Dolishnya, as a rule, companies in the oil and gas industry expect such obligations, based on the estimation of oil and gas reserves and the planned level of their production per year [12, p. 155].

The basis for determining the reserve for the decommissioning of fixed assets in the practice of accounting for oil and gas enterprises is dependent on the volumes of hydrocarbon production. However, there is a need for further research on the question of capitalization of costs and stages of the subsoil process, in which it is expedient, since it is not possible to estimate oil and gas reserves before the beginning of the industrial development of mineral deposits of mineral resources, their assessment is specified in the process of exploitation of deposits.

Recognition of provisions for the decommissioning or liquidation of fixed assets from the moment of exploration of mineral deposits is not permissible, since the obligation to dismantle industrial structures arises later in the course of their construction, and some additional obligations are already in the process of extraction. Provision for the disposal and liquidation of fixed assets should be recognized and capitalized, at least during the development or construction of wells, that is, before the start of the extraction process. Therefore, the recognition of provisions in the amount estimated on the basis of oil and gas reserves and the planned level of their extraction is appropriate in the process of oil and gas production.

At other stages of the process of subsoil use, the obligation to decommission non-current tangible assets should be recognized in the light of changes in previous estimates of resource gains and risks arising from the decommissioning of such assets and are characteristic of such an obligation. In total, the obligation should be the best estimate of future costs associated with the cessation of the use of such assets or the restoration of land plots.

Such an estimate is based on the calculations made by the technical experts, which take into account the technological indicators of the development of such oil and gas deposits, since the costs of the cessation of exploitation of fixed assets will vary depending on the location of the deposit, extraction technologies and other factors that affect the production process.

Provision of expenses for the decommissioning of fixed assets and the restoration of land plots is proposed to account for a separate subaccount 478 to the account 47 "Provision of future costs and payments", with the change of its name to "Provision of costs for decommissioning fixed assets and restoration of land". In the account of the reflection of such security, it is suggested to carry out the events, which are illustrated in Fig. 1

This amount is capitalized on the cost of property, plant and equipment and amortized over the useful life of the relevant method in accordance with the accounting policies of the oil and gas company.

If the reason for the change in the valuation is to change the amount of expected liabilities or to change the discount rate, then the amount of the change should be attributed to the initial value of fixed assets, as evidenced by the records illustrated in Fig. 2. 
Initial recognition of the amount of accounting in the account will be reflected in the accounting records:

Dt of account 10 "Fixed assets"

$\mathrm{Ct}$ of account 478 "Provision of expenses for the decommissioning of fixed assets and the restoration of land".

Fig. 1. The accounting of operations for forming the provision of expenses

for the decommissioning of fixed assets and the restoration of land plots

- with decreasing expectations:

Dt of account 478 "Provision of expenses for the decommissioning of fixed assets and the restoration of land"

Ct of account 10 "Fixed assets";

- with increasing expectations:

Dt of account 10 "Fixed assets"

$\mathrm{Ct}$ of account 478 "Provision of expenses for the decommissioning of fixed assets and the restoration of land"

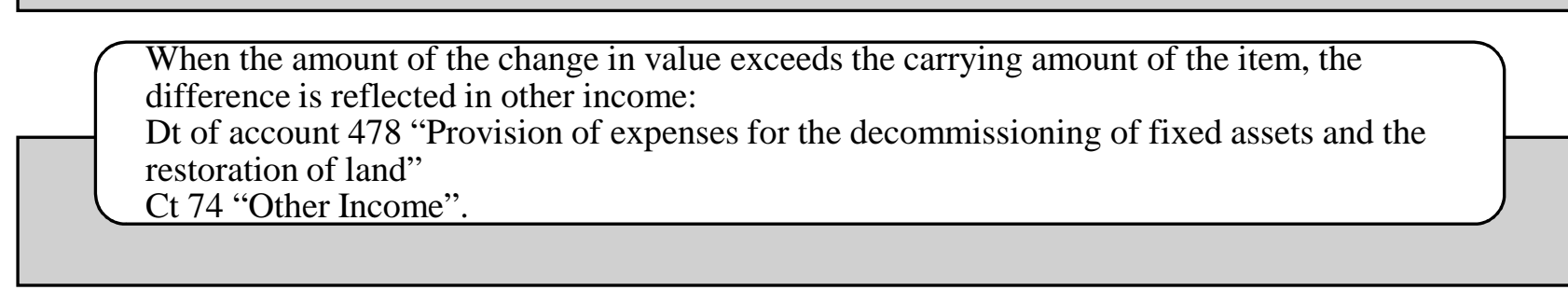

Fig. 2. Accounting for transactions arising from a change in the estimation of the provision of expenses for the decommissioning of fixed assets and the restoration of land plots

In the event that the change leads to an excess of the asset over its recoverable amount, that excess should be recognized as an impairment of the asset (impairment) in accordance with IAS 36, "Impairment of assets", at the time of the debit of the account 972 "Impairment losses on assets" and a credit of the account 10 "Fixed assets".

In order to realize the qualitative characteristics of financial reporting, in the part of information on the formation of provision for the decommissioning of fixed assets from the operation and restoration of land in the oil and gas industry, it is proposed to form them in the amount estimated on the basis of oil and gas reserves and the planned level of mineral extraction. At other stages of the subsoil process, it is recommended to take into account changes in previous estimates of the amount of resources embodying economic benefits and that are necessary to repay such an obligation, taking into account the risks of such processes. At initial recognition, the provision is capitalized into future expenses in the amount of discounted value of collateral and is shown in terms of the value of oil and gas assets. Subsequently, the asset created is amortized, and changes in the provision for provisioning are recognized as financial expenses of the current period.

\section{Conclusions and perspectives of further research in this direction}

1. Recognition of provisions in the amount calculated on the basis of oil and gas reserves and the planned level of their extraction, it is expedient to carry 


\section{Orlova, S. Kafka, O. Riabkova}

out in the process of oil and gas production. At other stages of the process of subsoil use of recognition of commitments for the decommissioning of fixed assets should be made taking into account changes in estimates of volumes of extracted resources that embody the economic benefits necessary to repay this obligation and taking into account risks.

2. In the financial statements, provision should be made at current cost. At initial recognition, the provision is capitalized into future expenses in the amount of discounted value and is shown in terms of the value of oil and gas assets.

3. The asset created subsequently is depreciated, and changes in the provision for provisioning should be reflected in financial expenses.

4. As a result, the formation of the provision of costs for the decommissioning of fixed assets from the operation and restoration of land will contribute to the implementation of qualitative characteristics of financial reporting for management purposes.

\section{References}

1. Osnovni zasoby: Polozhennia (standart) bukhhalterskoho obliku 7 [Fixed assets: Regulation (standard) of accounting 7]. (2000, April 27). Nakaz Ministerstva finansiv Ukrainy № 92 - The order of the Ministry of Finance of Ukraine №92. Retrieved from http://www.minfin.gov.ua/control/ uk/publish/article?art_id=340510\&cat_id=293533 [in Ukrainian].

2. Osnovni zasoby: Mizhnarodnyi standart bukhhalterskoho obliku 16 [Property, Plant and Equipment: International Accounting Standard 16]. (2012). Retrieved from https://zakon.rada.gov.ual laws/show/929_014 [in Ukrainian].

3. Hrinko, A. P. (2015). Teoretyko-metodolohichni zasady bukhhalterskoho obliku vidtvorennia osnovnoho kapitalu $v$ umovakh novoi upravlinskoi paradyhmy [Theoretical and methodological principles of accounting of reproduction of fixed capital in the conditions of the new administrative paradigm]. Kharkiv: KhDUKhT. [in Ukrainian].

4. Zadorozhnyi, Z. V. (2009). Problemni aspekty obliku osnovnykh zasobiv [Problem aspects of accounting of fixed assets]. Proceedings from XIV Mizhnarodna naukovo-praktychna konferentsiia «Perspektyvy rozvytku ekonomiky Ukrainy: teoriia, metodolohiia, praktyka" - 6th International Conference "Prospects for the development of the Ukrainian economy: theory, methodology, practice”. (pp.346-347). Lutsk: Volyn. nats. un-t im. Lesi Ukrainky[in Ukrainian].

5. Kizo, D. I., Veygant, D. Z., \& Uorfild, T. D. (2001). Finansovyy uchet [Financial Accounting] (9th ed.). N'yu-York: John Wiley\&Sons, Inc. [in Russian].
6. Kuznetsova, S. A., \& Kuznetsov, A. A. (2018). Transformatsiia metodolohii ta orhanizatsii bukhhalterskoho obliku y upravlinskoho kontroliu neoborotnykh materialnykh aktyviv $v$ umovakh informatsiinoi asymetrii ta virtualizatsii [Transformation of the methodology and organization of accounting and management control of nonnegotiable tangible assets under conditions of information asymmetry and virtualization]. Efektyvna ekonomika - Effective economy, 8. Retrieved from http://www.economy.nayka. com.ua/pdf/8_2018/7.pdf [in Ukrainian].

7. Krupka, Y. D. (2017). Kapitalizatsiia vytrat v obliku pidpryiemstv $z$ vydobuvannia ta pererobky pryrodnykh resursiv [Capitalization of expenses in accounting of enterprises on extraction and processing of natural resources]. Hlobalni ta natsionalni problemy ekonomiky - Global and national problems of the economy, 18, 544-549. Retrieved from http://global-national.in.ua/archive/ 18-2017/103.pdf [in Ukrainian].

8. Nidlz, B., Anderson, X., \& Kolduell, D. (1993). Printsipy bukhgalterskogo ucheta [Principles of accounting]. Moscow: Finansy i statistika. [in Russian].

9. Polozhennia pro poriadok likvidatsii naftovykh, hazovykh ta inshykh sverdlovyn i spysannia vytrat na yikh sporudzhennia pryiniatyi 27 hrudnia 1989 roku [Regulations on the procedure for the elimination of oil, gas and other wells and the writeoff of costs for their construction from December 27 1989]. Retrieved from: http://zakon5.rada.gov.ual laws/show/v0019400-89 [in Ukrainian].

10. Zabezpechennia, umovni zoboviazannia y umovni aktyvy: Mizhnarodnyi standart bukhhalterskoho obliku 37 [Provisions, Contingent Liabilities and Contingent Assets: International Accounting Standard 37]. (2012). Retrieved from http://zakon. rada.gov.ua/laws/show/929_051 [in Ukrainian].

11. Zoboviazannia: Polozhennia (standart) bukhhalterskoho obliku 11 [Obligations: Regulation (standard) of accounting 11]. (2000, January 31). Nakaz Ministerstva finansiv Ukrainy № 20 - The order of the Ministry of Finance of Ukraine №20 Retrieved from: http://zakon.help/ article/polozhennya-standart-buhgalterskogoobliku-11 [in Ukrainian].

12. Dolishnia, T. I. (2013). Oblik zabezpechennia vytrat na vyvedennia z ekspluatatsii osnovnykh zasobiv ta vidnovlennia zemelnykh dilianok: mizhnarodnyi $i$ natsionalnyi aspekty [Accounting for the provision of expenses for the decommissioning of fixed assets and the restoration of land: international and national aspects]. Visnyk Khmelnytskoho natsionalnoho universytetu - Herald of Khmelnytskyi national university, 3, 1(200), 154159 [in Ukrainian]. 